\title{
Poliomyelitis in ancient Greece (5th century BC)?
}

Elena Varotto, MA, PGD, Valentino Nizzo, PhD, and Francesco M. Galassi, MD

Correspondence

Neurology ${ }^{\circledR} 2019 ; 92: 678-679$. doi:10.1212/WNL.0000000000007350

Prof. Galassi

francescom.galassi@

flinders.edu.au

Figure Red figure Attic peliké and detail
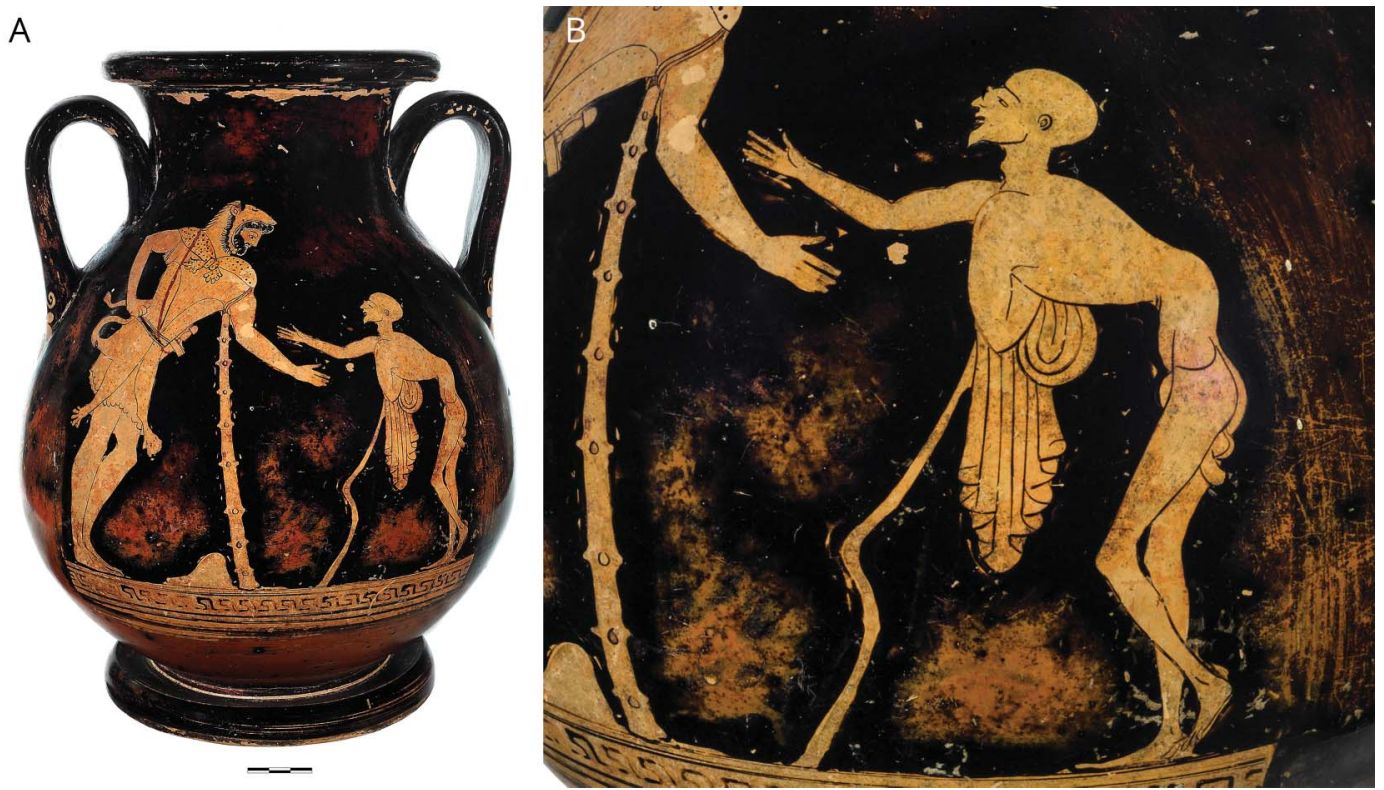

(A) Red figure Attic peliké from Tomb 432 of the Banditaccia Necropolis (Cerveteri, ancient Etruria, Lazio Region, Italy). Inv. No.: 48238 MiBAC. National Etruscan Museum of Villa Giulia (Rome). Photographs by Mauro Benedetti. (B) Detail of Geras shows the high degree of spinal deformity and muscular atrophy.

The antiquity of poliomyelitis is disputed, since only inconclusive evidence has been adduced for the Ancient World so far. ${ }^{1}$ A са 480 вС Attic peliké vase imported into Etruria (ancient Central Italy) depicting the mythical rendezvous between Heracles and Geras (figure, A) shows the latter (figure, B), the personification of Old Age, helping himself with a stick. The high degree of realism of this artwork, emerging in this historical period, allows one to identify extensive lower limb muscular atrophy and an unnatural eye-catching kyphoscoliotic spinal deformity. While previously considered-prudently yet perhaps too hurriedly-but a depiction of senile emaciation and pulmonary emphysema, ${ }^{2}$ the characteristically vivid clinical association leads us to hypothesize that Geras' anatomical features are compatible with those of a polio survivor exhibiting the incapacitating and long-term outcomes of the spinal form of paralytic poliomyelitis.

\section{Author contributions}

E. Varotto: concept creation, data acquisition, main writing. V. Nizzo: critical revision of the manuscript. F.M. Galassi: study design, data processing, writing, study supervision.

From Centre for Cretan Archaeology (E.V.), Department of Humanities (DISUM), University of Catania; National Etruscan Museum of Villa Giulia (V.N.), Rome; Santa Lucia Clinic-Polydiagnostic Medical Centre (E.V., F.M.G.), Siracusa, Italy; and Archaeology (F.M.G.)., College of Humanities, Arts and Social Sciences, Flinders University, Adelaide, Australia.

Go to Neurology.org/N for full disclosures. Funding information and disclosures deemed relevant by the authors, if any, are provided at the end of the article 


\section{Study funding}

No targeted funding reported.

\section{Disclosure}

The authors report no disclosures relevant to the manuscript.

Go to Neurology.org/N for full disclosures.

\section{References}

1. Galassi FM, Habicht ME, Rühli FJ. Poliomyelitis in ancient Egypt? Neurol Sci 2017; 38:375.

2. Grmek D, Gourevitch D. Le Malattie nell'Arte Antica. Firenze: Giunti Editore; 2000: 136-139.

\section{Subspecialty Alerts by E-mail!}

Customize your online journal experience by signing up for e-mail alerts related to your subspecialty or area of interest. Access this free service by clicking on the "My Alerts" link on the home page. An extensive list of subspecialties, methods, and study design choices will be available for you to choose from-allowing you priority alerts to cutting-edge research in your field!

\section{Share Your Artistic Expressions in Neurology 'Visions'}

AAN members are urged to submit medically or scientifically related artistic images, such as photographs, photomicrographs,

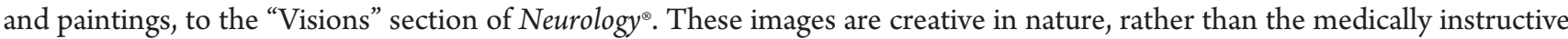
images published in the NeuroImages section. The image or series of up to six images may be black and white or color and must fit into one published journal page. Accompanying description should be 100 words or less; the title should be a maximum of 96 characters including spaces and punctuation.

Please access the Author Center at NPub.org/authors for full submission information.

\section{Sign Up for the AAN's Axon Registry}

The AAN encourages its US members to show their interest in participating in the Axon Registry by signing up today.

Use the Axon Registry to:

- Simplify reporting requirements under MACRA's Quality Payment Program and avoid penalties while reducing your administrative burden

- Meet your MOC Part IV requirements and waive up to eight credits of Part II Self-Assessment

- Choose from 22 AAN neurology-specific quality measures that fit your practice

- Use data to understand your practice and identify where improvements can be made to patient care

- Manage your patients at a population level; look at a specific group of patients based on conditions, risk factors, demographics or outcome

- Demonstrate your value to payers when negotiating reimbursement

- Enjoy multi-year, fee-free access when you sign the agreements and integrate your EHR with the registry

Learn more at AAN.com/view/Axon and send your questions to registry@aan.com. 


\title{
Neurology
}

\author{
Poliomyelitis in ancient Greece (5th century BC)? \\ Elena Varotto, Valentino Nizzo and Francesco M. Galassi \\ Neurology 2019;92;678-679 \\ DOI 10.1212/WNL.0000000000007350
}

This information is current as of April 1, 2019

\section{Updated Information \& Services}

\section{References}

Subspecialty Collections

Permissions \& Licensing

Reprints including high resolution figures, can be found at: http://n.neurology.org/content/92/14/678.full

This article cites 1 articles, 0 of which you can access for free at: http://n.neurology.org/content/92/14/678.full\#ref-list-1

This article, along with others on similar topics, appears in the following collection(s):

Anterior nerve cell disease

http://n.neurology.org/cgi/collection/anterior_nerve_cell_disease Muscle disease

http://n.neurology.org/cgi/collection/muscle_disease

Public health

http://n.neurology.org/cgi/collection/public_health

Viral infections

http://n.neurology.org/cgi/collection/viral_infections

Information about reproducing this article in parts (figures,tables) or in its entirety can be found online at:

http://www.neurology.org/about/about_the_journal\#permissions

Information about ordering reprints can be found online:

http://n.neurology.org/subscribers/advertise

Neurology ${ }^{\circledR}$ is the official journal of the American Academy of Neurology. Published continuously since 1951, it is now a weekly with 48 issues per year. Copyright (O 2019 American Academy of Neurology. All rights reserved. Print ISSN: 0028-3878. Online ISSN: 1526-632X.

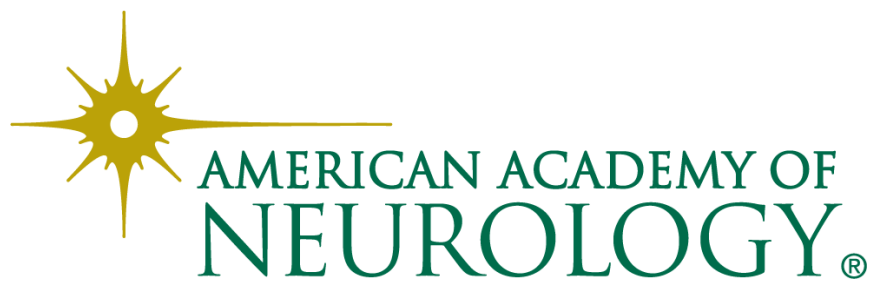

